\title{
PERLINDUNGAN HUKUM TERHADAP ANAK AKIBAT PERCERAIAN ORANG TUA
}

\author{
Oleh: \\ Putu Sauca Arimbawa Tusan ${ }^{1}$
}

\begin{abstract}
Legal protection is the right of every citizen including the right for children. All citizens are equal before the law and government and shall abide by the law and the government without any exception. The state should make laws as commander in safeguarding the implementation of national and state life. Every child has the right to live, grow and develop and are entitled to protection and violence and discrimination. Divorce cases in particular Denpasar Bali every year showed an increase. It is necessary to get the attention of the parties concerned, because of the impact of divorce experienced by children can be felt directly by the children themselves. Children become victims direct result of his parents' divorce. The judiciary has an important role to ensure the rights of children through a court decision. Judges who hear cases of divorce may consider in its decision to regulate the rights of children whose parents did divorce. This research with the normative methods research type, which aims to provide a clear picture of the setting and the role of judges in providing legal protection for child victims of divorce.
\end{abstract}

Keywords: Legal protection Children, Divorce

\begin{abstract}
Abstrak
Perlindungan hukum merupakan hak bagi setiap warga negara termasuk juga hak bagi anak. Segala warga negara bersamaan kedudukannya di dalam hukum dan pemerintahan dan wajib menjunjung hukum dan pemerintahan itu dengan tidak ada kecualinya. Negara harus menjadikan hukum sebagai panglima dalam mengawal penyelenggaraan kehidupan berbangsa dan bernegara. Setiap anak berhak atas kelangsungan hidup, tumbuh dan berkembang serta berhak atas perlindungan dan kekerasan dan diskriminasi. Kasus perceraian di Bali khususnya kota Denpasar setiap tahunnya memperlihatkan adanya peningkatan. Hal ini perlu mendapatkan perhatian oleh pihak terkait, karena dampak perceraian yang dialami anak dapat dirasakan langsung oleh anak itu sendiri. Anak menjadi korban langsung akibat perceraian orang tuanya. Lembaga peradilan mempunyai peranan penting untuk menjamin hak-hak anak lewat putusan pengadilan. Hakim yang memeriksa perkara perceraian misalnya dapat mempertimbangkan dalam putusan nya untuk mengatur tentang hak-hak anak yang orang tuanya melakukan perceraian. Penelitian ini menggunakan metode penelitian hukum normatif, yang bertujuan untuk memberikan gambaran yang jelas tentang pengaturan dan peranan hakim dalam memberikan perlindungan hukum bagi anak korban akibat perceraian.
\end{abstract}

Kata kunci: Perlindungan Hukum, Anak, Perceraian

1 Jaksa Fungsional Pada Kejaksaan Negeri Denpasar, Bali. Email : saucaarimbawa@yahoo.com 


\section{PENDAHULUAN}

Manusiasebagaimahlukindividu yang mandiri tidak dapat hidup tanpa adanya bantuan dari manusia lainnya, maka dari itu manusia dikatakan sebagai mahluk sosial. Manusia selalu berinteraksi pada lingkungan masyarakat secara langsung maupun tidak langsung karena adanya suatu kepentingan, persamaan keinginan atau karena adanya suatu perasaan pada diri masing-masing manusia tersebut. Manusia diciptakan dengan hidup berpasangan dan hubungan tersebut dilakukan dengan adanya perkawinan.

Perkawinan yang dilangsungkan oleh seorang laki-laki dengan seorang perempuan memiliki tujuan untuk mencegah terjadinya hal-hal yang tidak diamanatkan oleh agama, nilai-nilai yang terkandung dalam masyarakat, dan peraturan perundang-undangan yang berlaku. Tujuan perkawinan salah satunya adalah membentuk sebuah keluarga lalu menghasilkan sebuah keturunan yaitu anak.

Anak yang merupakan hasil dari sebuah perkawinan merupakan suatu hal yang sangat penting dalam suatu kehidupan berkeluarga, oleh karena anak sangat berpotensi terhadap nasib suatu generasi atau bangsa di masa mendatang, dan merupakan suatu cerminan sikap hidup bangsa dan penentu perkembangan bangsa tersebut ${ }^{2}$. Masa kanak-kanak

2 Wagiati Sutedjo, 2010, Hukum Pidana Anak, Cetakan Ketiga, PT.Refika Aditama, Bandung, hlm. 5 seharusnya dilewati dengan masa pembentukan watak, pembentukan kepribadian dan juga pembentukan karakter diri seorang anak, agar anakanak tersebut kelak memiliki kekuatan dan kemampuan dalam menjalani kehidupan di masa mendatang ${ }^{3}$.

Hal tersebut menjadikan posisi anak sebagai suatu keharusan yang perlu untuk diperhatikan serta mendapat segala perlindungan dan juga kebutuhan yang sesuai dengan kebutuhan anak itu sendiri. Pada jaman yang serba modern ini banyak sekali terjadikasusanakyangmengalamisuatu tindak kekerasan dalam kehidupannya. Kekerasan tersebut umumnya terjadi di lingkungan terdekatnya yaitu di lingkungan keluarganya sendiri.

Kekerasan terhadap anak atau yang sering disebut dengan child abuse merupakan suatu tindakan kekerasan terhadap perlakuan fisik, mental, atau seksual yang pada umumnya dilakukan oleh orang terdekat yakni keluarga yang mana itu semua diindikasikan dengan kerugian dan ancaman terhadap kesehatan dan kesejahteraan anak. Bentuk-bentuk kekerasan terhadap anak atau child abuse selain berupa kekerasan terhadap perlakuan fisik, mental, atau seksual, juga dapat berupa berbagai eksploitasi seperti misalnya pornografi dan penyerangan seksual (sexual assault), pemberian makanan yang tidak layak bagi anak atau

3 Maidin Gultom, 2008, Perlindungan Hukum Terhadap Anak dalam Sistem Peradilan Pidana Anak di Indonesia, Refika Aditama, Bandung, hlm. 1. 
makanan kurang gizi (malnutrition), pengabaian pendidikan dan kesehatan (educational and medical neglect) dan kekerasan-kekerasan yang berkaitan dengan medis (medical abuse) juga yang paling marak saat ini yaitu penelantaran setelah perceraian ${ }^{4}$. Berbagai kasus telah membuktikan bahwa terjadinya kekerasan terhadap anak sering juga disertai dengan penelantaran terhadap anak. Baik penganiayaan maupun penelantaran terhadap anak dapat memberikan dampaknegatifpadakesehatan fisik dan juga kesehatan mental anak tersebut ${ }^{5}$. Dampak negatif tersebut dapat berupa gejala depresi, jati diri yang rendah, kecemasan, adanya gangguan tidur, phobia, kelak dapat tumbuh menjadi seorang penganiaya, menjadi bersifat keras, gangguan stres pasca trauma dan juga yang lebih penting dapat terlibat dalam penyalahgunaan narkotika ${ }^{6}$.

Maka dari itu perlunya suatu perlindungan hukum terhadap anak, salah satunya yaitu dengan upaya perlindungan yang diberikan hukum terhadap berbagai kebebasan dan hak asasi anak, serta berbagai kepentingan yang berhubungan dengan kesejahteraan anak ${ }^{7}$ Anak perlu mendapat perlindungan agar tidak mengalami kerugian, baik

4 Bagong Suyanto dan Sri Sanituti, 2002, Krisis \& Child Abuse, Airlangga University, Surabaya, hlm. 114

$5 \quad$ Ibid., hlm. 122

$6 \quad$ Ibid., hlm. 123

7 Agustinus Pohan, Topo Santoso, dan Martin Moerings (ed), 2012, Hukum Pidana Dalam Perspektif, Pustaka Larasan, Denpasar, hlm, 267. mental, fisik, maupun sosial ${ }^{8}$. UndangUndang Dasar Negara Republik Indonesia Tahun 1945 Pasal 27 Ayat (1) secara tegas menyatakan bahwa: "Segala warga negara bersamaan kedudukannya di dalam hukum dan pemerintahan dan wajib menjunjung hukum dan pemerintahan itu dengan tidak ada kecualinya". Demikian juga adalah konsekuensi bagi Negara Republik Indonesia yang menetapkan dalam konstitusi nya sebagai negara hukum, sehingga hukum harus menjadi panglima dalam mengawal penyelenggaraan kehidupan berbangsa dan bernegara. Hukum menjadi pelindung bagi setiap warga negara, tidak terkecuali anak. Hukum berdiri di atas semua individu, kelompok, maupun golongan. Hukum menjadi payung bagi seluruh rakyat Indonesia, sehingga salah asas hukum yang dijunjung tinggi adalah equality before the law, memperlakukan setiap warga negara bersamaan kedudukannya di depan hukum.

Berbicara mengenai perceraian, fenomena maraknya perceraian dalam rumah tangga di Bali, khususnya pada kota Denpasar perlu mendapat perhatian serius, mengingat angka perceraian memperlihatkan tren yang terus meningkat dari tahun ke tahun. Data dari Dinas Kependudukan dan Catatan Sipil kota Denpasar serta Pengadilan Agama Denpasar, jumlah kasus perceraian yang tercatat tahun 8 Maidin Gultom, 2012, Perlindungan HukumTterhadap Anak Dan Perempuan, Bandung: PT. Refika Aditama, hlm. 69. 
2015 sebanyak 742 kasus. Tahun 2016 sebanyak 906 kasus atau meningkat 164 kasus dari tahun 20159. Jumlah kasus perceraian tersebut tentunya amat sangat disayangkan, oleh karena harapan sebenarnya adalah bagaimana meminimalisir angka perceraian ke titik terendah, meskipun undang-undang memberi jalan untuk perceraian, namun perceraian harus menjadi pilihan terakhir setelah pengadilan telah berusaha sedemikian rupa untuk mendamaikan pihak yang berselisih, namun tidak berhasil.

Berbicara mengenai perceraian, maka sesungguhnya undang-undang sendiri dalam hal ini memberikan peluang bagi para pihak baik suami ataupun istri untuk bercerai. Perceraian tersebut dalam undangundang masih memberikan adanya syarat dan ketentuan yang rumit untuk terjadinya perceraian, misalnya perceraian hanya bisa dilakukan di depan sidang pengadilan setelah pengadilan tidak dapat merukunkan. Hal tersebut tidak lain tujuannya adalah untuk tidak menggampangkan para pihak untuk bercerai. Adapun upaya-upaya yang dilakukan agar para pihak tidak melakukan perceraian, misalnya dengan menetapkan mediasi

9 Tribun Bali, 2017, Istri yang Paling Banyak Minta Cerai di Denpasar, Dipicu Medsos Hingga Urusan Ranjang, available from: URL: http://bali. tribunnews.com/2017/03/11/istri-yangpaling-banyak-minta-cerai-di-denpasardipicu-medsos-hingga-urusan-ranjang , diakses tanggal 15 Maret 2017 sebagai syarat imperatif dalam proses pemeriksaan perkara perceraian.

Pengadilan yang sudah melakukan upaya mediasi, namun tidak dapat mendamaikan para pihak yang akan bercerai, maka dalam hal ini pengadilan harus memutuskan yang terbaik dan adil dari akibat yang ditimbulkan dari perceraian tersebut. Akibat dari perceraian yang terjadi tidak serta rnerta akan mengakhiri segala kewajiban dan tanggung jawab dari pihak yang bercerai.

Pengadilan dalam hal ini perlu memperhatikan dan mempertimbangkan nasib dan masa depan anak yang lahir dari proses perkawinan tersebut sebelum memutus perkara perceraian. Kesejahteraan dan kepentingannya anak yang lahir dari perkawinan tersebut harus dapat dilindungi dan juga diperhatikan. Anak akibat perceraian orang tuanya akan merasakan dampak yang paling nyata berupa tekanan psikologis, sehingga cukuplah anak sengsara dengan beban psikologinya, jangan sampai anak menjadi korban (victim) akibat hak-hak keperdataan anak diabaikan. Secara konstitusi, telah tegas dalam memberikan jaminan bagi kelangsungan hidup, tumbuh dan berkembang anak sebagaimana tercantum dalam Pasal 28 B Ayat (2) UUD 1945 yang menyatakan bahwa: "Setiap anak berhak atas kelangsungan hidup, tumbuh dan berkembang serta berhak atas perlindungan dari kekerasan dan diskriminasi”. 
Berdasarkan latar belakang di atas, dalam penelitian ini dapat ditentukan rumusan masalahnya adalah sebagai berikut:

\section{Bagaimanakah pengaturan}

perlindungan hukum bagi anak korban perceraian?

2. Bagaimanakah peranan hakim dalam melindungi hak-hak anak korban perceraian tersebut?

Penelitian karya ilmiah ini merupakan penelitian asli yang sampai saat ini belum pernah diteliti sebelumnya. Karya ilmiah yang terkait dengan karya ilmiah Penulis tentang Perlindungan Hukum Bagi Anak Akibat Perceraian Orang Tua yaitu karya ilmiah dari Izzah Amila Faisal tahun 2015 dengan judul Pariwisata Seksual Anak : Upaya Perlindungan Anak Berkaitan Dengan Sex Child Tourism yang rumusan masalahnya adalah; 1. Apakah faktor penyebab terjadinya pariwisata seksual anak?; 2. Bagaimana upaya meningkatkan perlindungan hukum terhadap anak terhadap dampak negatif dari perkembangan pariwisata? ${ }^{10}$. Karya ilmiah selanjutnya yang terkait yaitu Ni Nyoman Sukerti tahun 2015 dengan

10 Faisal, Izzah Amila. PARIWISATA SEKSUAL ANAK : UPAYA PERLINDUNGAN ANAK BERKAITAN DENGAN SEX CHILD TOURISM. Jurnal Magister Hukum Udayana (Udayana Master Law Journal), vol. 4 no. 4 edisi desember 2015 . < <ttps://ojs.unud.ac.id/index. php/jmhu/article/view/19739>,Diakses tanggal 9 maret 2017. doi: <https://doi. org/10.24843/JMHU.2015.v04.i04.p01. judul Penegakan Hukum Terhadap Hak Asuh Anak Akibat Perceraian Dalam Praktik Peradilan Di Bali yang rumusan masalahnya adalah; 1 . Hukum apakah diterapkan oleh hakim terkait hak asuh anak akibat perceraian dalam hal berlakunya pluralisme hukum?; 2. Faktor-faktor apakah yang menjadi dasar pertimbangan hakim dalam menetapkan hak asuh anak akibat perceraian? ${ }^{11}$. Pada penelitian yang dibuat oleh Penulis ini, nampak keunggulan karya ilmiah ini dari karya ilmiah lainnya yaitu membahas lebih mendalam tentang pengaturan perlindungan hukum bagi anak korban perceraian dan membahas tentang peranan hakim dalam melindungi hakhak anak korban perceraian.

Tujuan dari penelitian ini adalah untuk memberikan gambaran yang jelas tentang pengaturan dan peranan hakim dalam memberikan perlindungan hukum bagi anak korban akibat perceraian.

\section{METODE PENELITIAN}

Penelitian hukum adalah segala kegiatan penulis untuk membahas permasalahan-permasalahan hukum,

11 Sukerti, Ni Nyoman. PENEGAKAN HUKUM TERHADAP HAK ASUH ANAK AKIBAT PERCERAIAN DALAM PRAKTIK PERADILAN DI BALI. Jurnal Magister Hukum Udayana (Udayana Master Law Journal), vol. 4 no. 1 edisi mei 2015. $<$ https://ojs.unud.ac.id/index.php/ jmhu/article/view/13043>.. Diakses tanggal 9 maret 2017. doi: <https://doi. org/10.28483/JMHU.2015.v04.i01.p07. 
baik yang bersifat akademik maupun praktis, baik yang bersifat asas-asas hukum atau norma-norma hukum yang hidup dan berkembang dalam masyarakat berdasarkan dengan kenyataan hukum dan masyarakat ${ }^{12}$. Pada penelitian karya ilmiah ini, Penulis menggunakan metode penelitian hukum normatif. Mukti Fajar ND dan Yulianto Ahmad berpendapat bahwa penelitian hukum normatif merupakan suatu penelitian hukum yang meletakkan hukum sebagai sistem norma, mengenai asasasas, norma, kaidah dari peraturan perundang-undangan, putusan pengadilan, perjanjian serta doktrin $(\text { ajaran })^{13}$.

Penulisan penelitian karya ilmiah ini oleh Penulis, bahan hukum yang diperoleh dari bahan hukum primer, bahan hukum sekunder dan juga bahan hukum tersier selanjutnya diteliti, dengan mempergunakan pendekatan perundang-undangan (the statute approach) yang berhubungan dengan masalah yang dibahas yang bertujuan untuk memecahkan suatu permasalahan ${ }^{14}$.

12 Zainuddin Ali, 2009, Metode Penelitian Hukum, Sinar Grafika, Jakarta, hlm.19

13 Mukti Fajar ND dan Yulianto Achmad, 2010, Dualisme Penelitian Hukum Normatif dan Hukum Empiris, Pustaka Pelajar, Yogyakarta, hlm. 34.

14 Peter Mahmud Marzuki, 2011, Penelitian Hukum, Kencana Prenada Media Group, Jakarta, hlm. 93
III. HASIL DAN PEMBAHASAN

\subsection{Pengaturan Perlindungan} Hukum Bagi Anak Korban Perceraian

Perlindungan hukum terhadap anak merupakan suatu usaha atau kegiatan oleh seluruh lapisan masyarakat dalam berbagai kedudukan yang menyadari betul pentingnya anak bagi bangsa dan negara di kemudian hari ${ }^{15}$. Menurut pendapat dari Philipus M. Hadjon, perlindungan hukum dapat dibedakan menjadi dua macam perlindungan hukum, yaitu: perlindungan hukum yang bersifat preventif dan perlindungan hukum yang bersifat represif. Pada perlindungan hukum yang preventif kepada masyarakat diberikan kesempatan untuk mengajukan keberatan (inspraak) atau pendapatnya sebelum suatu keputusan pemerintah mendapat bentuk yang definitif. Dengan demikian, perlindungan hukum yang preventif bertujuan untuk mencegah terjadinya sengketa, sedangkan sebaliknya perlindungan hukum yang represif bertujuan untuk rnenyelesaikan sengketa. Pengertian perlindungan hukum yang bersifat represif adalah penanganan perlindungan hukum bagi rakyat oleh lembaga peradilan, yaitu Peradilan Umum dan Peradilan Administrasi ${ }^{16}$.

Situasi yang kian memburuk dan juga perlakuan yang tidak wajar dialami

15 Maidin Gultom, 2008, Op.Cit., hlm. 33

16 Philipus M. Hadjon, 2007, Perlindungan Hukum Bagi Rakyat Indonesia, Peradaban, Jakarta, hlm. 3 
oleh anak pada umumnya di berbagai belahan dunia membuat keinginan PBB untuk merumuskan instrumen hak-hak anak. Pada tahun 1989 PBB berhasil mengesahkan menjadi suatu Konvensi Hak Anak atau yang sering disebut dengan United Nation's Convention on the Rights of the Child. Indonesia merupakan negara peserta anggota PBB yang telah mengikatkan dirinya secara hukum (legally binding) dengan meratifikasi Konvensi Hak Anak pada tahun 1990. Langkah hukum ratifikasi ini dilakukan dengan berdasarkan Keputusan Presiden (Keppres) No. 36 Tahun 1990 tentang Pengesahan Peratifikasian Konvensi Hak Anak.

\section{Lahirnya Undang-Undang} Nomor 23 Tahun 2002 tentang Perlindungan Anak yang pada saat ini telah dirubah dengan UndangUndang Nomor 35 Tahun 2014 tentang Perubahan Atas Undang-Undang Nomor 23 Tahun 2002 Tentang Perlindungan Anak, adalah jawaban atas ratifikasi Konvensi Hak Anak tersebut. Pada ketentuan Pasal 1 angka 2 Undang-Undang Nomor 35 Tahun 2014 tentang Perubahan Atas UndangUndang Nomor 23 Tahun 2002 Tentang Perlindungan Anak, secara jelas menyatakan bahwa: "Perlindungan anak adalah segala kegiatan untuk menjamin dan melindungi anak dan hak-haknya agar dapat hidup, tumbuh, berkembang, dan berpartisipasi secara optimal sesuai dengan harkat dan martabat kemanusiaan, serta mendapat perlindungan dari kekerasan dan diskriminasi. Penulis berpendapat bahwa perlindungan hukum terhadap anak korban perceraian adalah segala bentuk perlindungan yang diberikan kepada anak (korban perceraian) yang mendukung bagi masa depan anak dan didasarkan pada peraturan perundangundangan serta dilakukan penegakan hukum secara konsisten oleh aparat penegak hukum demi tercapainya hakhak anak.

Peraturan perundang-undangan di Indonesia saat ini dalam memberikan perlindungan hukum bagi anak yang orang tuanya bercerai, tampak pada amanat konstitusi Pasal 28 B UUD 1945, beberapa peraturan perundangundangan lain baik undang-undang tersebut secara khusus mengatur tentang perlindungan pada hak-hak keperdataan anak, atau menjadi bagian dari suatu undang-undang. Undangundang yang khusus mengatur tentang perlindungan anak, misalnya Undang-Undang Nomor 23 Tahun 2002 tentang Perlindungan Anak, seperti salah satu pasalnya, yakni pada ketentuan Pasal 3 yang menyatakan bahwa: "Perlindungan anak bertujuan untuk menjamin terpenuhinya hakhak anak agar dapat hidup, tumbuh, berkembang, dan berpartisipasi secara optimal sesuai dengan harkat dan martabat kemanusiaan, serta mendapat perlindungan dari kekerasan dan diskriminasi, demi terwujudnya anak Indonesia yang berkualitas, berakhlak mulia, dan sejahtera." 
Sementara undang-undang yang mengatur perlindungan anak yang merupakan bagian dari suatu undangundang, misalnya Undang-Undang No. 1 Tahun 1974 tentang Perkawinan, Undang-Undang No. 24 Tahun 2004 tentang Penghapusan Kekerasan Dalam Rumah Tangga dan berbagai aturan lainnya.

Undang-Undang No. 1 Tahun 1974 tentang Perkawinan, misalnya beberapa pasalnya secara tegas mengatur tentang hak-hak anak yang orang tuanya bercerai, contohnya pada Pasal 45 Ayat (1) dan Ayat (2) disebutkan:

1) Kedua orang tua wajib memelihara dan mendidik anakanak mereka sebaik-baiknya.

2) Kewajiban orang tua yang dimaksud pada Ayat (1) pasal ini berlaku sampai anak itu kawin atau dapat berdiri sendiri, kewajiban mana berlaku terus meskipun perkawinan antara kedua orang tua putus.

Demikian juga dalam Pasal 41 Undang-Undang No. 1 Tahun 1974 tentang Perkawinan menyatakan bahwa:

Akibat putusnya perkawinan karena perceraian ialah:

a. Baik ibu atau bapak tetap berkewajiban memelihara dan mendidik anak-anaknya, sematamata berdasarkan kepentingan anak, bilamana ada perselisihan mengenai penguasaan anakanak, pengadilan memberi keputusannya; b. Bapak yang bertanggung jawab atas semua biaya pemeliharaan dan pendidikan yang diperlukan anak itu, bilamana bapak dalam kenyataan tidak dapat memenuhi kewajiban tersebut, pengadilan dapat menentukan bahwa ibu ikut memikul biaya tersebut;

c. Pengadilan dapat mewajibkan kepada bekas suami untuk memberikan biaya penghidupan dan/atau menentukan sesuatu kewajiban bagi bekas istri.

Demikian juga UndangUndang No. 23 Tahun 2004 tentang Penghapusan Kekerasan Dalam Rumah Tangga menyebutkan tentang perlindungan bagi anak misalnya pada ketentuan Pasal 9 Ayat (1) yang menyatakan bahwa: "Setiap orang dilarang menelantarkan orang dalam lingkup rumah tangganya, padahal menurut hukum yang berlaku baginya atau karena persetujuan atau perjanjian ia wajib memberikan kehidupan, perawatan, atau pemeliharaan kepada orang tersebut". Pasal 5 huruf d juga menyatakan bahwa: "Setiap orang dilarang melakukan kekerasan dalam rumah tangga, dengan cara; a. kekerasan fisik; b. kekerasan psikis; c. kekerasan seksual; atau d. penelantaran rumah tangga...".

Peraturan perundangan tersebut di atas secara jelas telah memberikan hak-hak keperdataan yang berhak didapatkan serta dari aspek hukum pidana terhadap anak yang menjadi korban perceraian, dan pengadilan 
pun dapat memutuskan yang terbaik bagi anak berdasarkan peraturan perundang-undangan yang telah disebutkan tersebut. Adapun dalam kaitannya fungsi hukum dengan perlindungan hukum menurut Philipus M. Hadjon adalah melakukan beberapa upaya yaitu upaya preventif dan upaya represif ${ }^{17}$. Upaya preventif, dalam hal ini adanya kesempatan untuk mengajukan keberatan (inspraak) atau pendapatnya sebelum suatu keputusan pemerintah mendapat bentuk yang definitif. Bentuk ini adalah berupa pedoman/pencegahan dalam bentuk ancaman terhadap pelaku pelanggar hukum, kehadiran hukum dengan berbagai sanksinya tersebut dapat menjadi instrumen untuk memberikan efek jera baik secara khusus (personal deterrence) maupun efek jera secara umum (general deterrence) memberikan rasa takut kepada masyarakat sehingga terhalang untuk melakukan tindakan melanggar hukum, jadi penekanannya pada upaya untuk mencegah terjadinya kejadian tersebut. Upaya represif, terkadang juga hukum muncul dengan wajahnya yang represif. Hukum yang represif adalah hukum yang mengabdi kepada kekuasaan represif dan kepada tata tertib sosial yang represif. Bila hukum tersebut dilanggar maka harus dilakukan penegakan hukum terhadap para pelanggarannya tersebut (law enforcement) tanpa pandang bulu. Dan untuk melakukan penegakan hukum

17 Philipus M. Hadjon, Op.Cit., hlm. 52 tersebut lembaga peradilan memiliki kewenangan dan kekuasaan untuk itu.

Penulis berpendapat bahwa pada dasarnya orang itu baik, namun terkadang lingkungan dan keadaan lah yang membuat orang menjadi tidak baik atau melanggar hukum. Dalam hal ini perlu untuk adanya suatu upaya agar dapat mengembalikan keadaan seperti semula. Hukum akan menjadi instrumen untuk membuat orang itu kembali menjadi baik dengan adanya hukuman yang diberikan kepada para pelanggar hukum. Dengan pemberian hukuman bermaksud selain membuat ia jera juga dapat menjadikan seseorang kembali menjadi baik sesuai dengan tujuan penghukuman yaitu agar dapat diterima kembali dengan masyarakatnya sehingga hukum juga dapat disebut sebagai instrumen rehabilitasi

\subsection{Peranan Putusan Hakim dalam Melindungi Hak-hak Anak}

Undang-undang dan berbagai peraturan lainnya mengenai perlindungan hak-hak anak tidaklah dapat berdiri sendiri, undang-undang tersebut haruslah dilaksanakan oleh para aparat penegak hukum yang baik dalam hal ini sistem peradilan pidana, khususnya lembaga peradilan. Dalam proses menerapkan dan menegakkan hukum tidak serta merta hanya dengan hukum itu sendiri, ada komponen lain yang dapat mendukung penerapan dan penegakan hukum. Proses bekerjanya 
hukum itu sendiri dipengaruhi oleh tiga komponen penting yang saling terkait satu sama lain. Menurut pendapat Otje Salman dan Anton F. Susanto bahwa penerapan dan penegakan hukum harus mencakup tiga komponen yang secara simultan berjalan melalui langkah-langkah strategis, mulai dari perencanaan pembuatan aturan (legislation planning), proses pembuatannya (law making procces), sampai kepada penegakan hukum (law enforcement) yang dibangun melalui kesadaran hukum (law awareness) masyarakat $^{18}$.

Berbicara mengenai penegakan hukum, putusan hakim merupakan suatu mahkota, hakim dalam membuat putusan wajib memperhatikan kehatihatian dan sedikit mungkin untuk dapat menghindari ketidakcermatan yang bersifat formal maupun materiil agar putusan hakim tersebut dapat terlihat kecakapan teknik membuatnya. Tujuannya agar dalam diri hakim dapat lahir, tumbuh, dan berkembang adanya sikap atau sifat kepuasan moral jika putusan yang dibuat itu dapat menjadi tolok ukur untuk kasus yang sama, sebagai bahan referensi bagi kalangan praktisi hukum serta kepuasan hati nurani tersendiri jika sampai dikuatkan dan tidak dibatalkan oleh tingkat pengadilan yang lebih tinggi ${ }^{19}$.

18 Otje Salman dan Anton F. Susanto, 2009, Teori Hukum Mengingat, Mengumpulkan dan Membuka Kembali, Refika Aditama, Bandung, hlm. 154

19 Lilik Mulyadi, 2007, Putusan Hakim dalam Hukum Acara Pidana, PT Citra Aditya Bakti, Bandung, hlm. 134
Salah satu komponen bekerjanya hukum yaitu hakim dapat memberikan perlindungan hukum terhadap anak korban perceraian lewat putusannya. Dalam setiap perceraian, pihak dari anak akan menjadi pihak yang paling dirugikan dan perlu menjadi salah satu pertimbangan dalam memutus atau meneruskan hubungan rumah tangga pasangan suami istri. Orang tua dalam hal bercerai tidak boleh mengorbankan masa depan anak, anak harus dilindungi hak-hak dan kepentingannya. Hakim dapat memberikan suatu perlindungan hukum terhadap anak tersebut sesuai dengan ketentuan Pasal 10 huruf a Undang-Undang No. 24 Tahun 2004 tentangPenghapusan Kekerasan Dalam Rumah Tangga yang menyatakan bahwa: korban berhak mendapatkan memberikan perlindungan dari pihak keluarga, kepolisian, kejaksaan, pengadilan, advokat, lembaga sosial, atau pihak lainnya baik sementara maupun berdasarkan penetapan perintah perlindungan dari pengadilan".

Dalam hal adanya suatu perceraian, hakim dapat memberikan suatu pertimbangan untuk memberikan hak-hak kepada anak korban perceraian, baik yang diminta oleh pihak yang beperkara ataupun yang tidak diminta. Hak-hak anak tersebut meliputi hak anak untuk hidup, hak anak untuk tumbuh dan berkembang terbebas dari berbagai bentuk penelantaran. Kedua orang tua anak yang akan bercerai tetap berkewajiban 
memelihara dan mendidik anakanaknya, seperti misalnya dalam hal ini orang tua laki-laki atau bapak yang bertanggungjawab atas semua biaya pemeliharaan dan pendidikan yang diperlukan anak, sampai anak tersebut dewasa dan mandiri atau sampai anak tersebut berumur 21 tahun. Beberapa pertimbangan oleh hakim dalam memberikan hak anak tersebut, dapat dikukuhkan dalam putusan nantinya.

Apabila orang tua melalaikan kewajibannya untuk memelihara dan memberikan nafkah kepada anak atau menelantarkan anak yang telah dikukuhkan dalam putusan pengadilan, maka pihak yang dirugikan dapat mengajukan permohonan eksekusi terhadap putusan tersebut. Namun jika hak-hak anak tersebut tidak ditetapkan dalam putusan pengadilan. Maka pihak yang dirugikan dapat mengajukan gugatan perdata ke pengadilan untuk menuntut hak-hak keperdataan anak yang telah diabaikan. Namun bila pihak yang merasa dirugikan tersebut tidak puas dengan gugatan perdata, maka pihak yang dirugikan dapat mengajukan laporan pidana kepada aparat penegak hukum dengan dasar pada ketentuan Pasal 13 ayat (1) Undang-Undang No. 23 Tahun 2002 tentang Perlindungan Anak yang menyatakan bahwa: Setiap anak selama dalam pengasuhan orang tua, wali, atau pihak lain mana pun yang bertanggung jawab atas pengasuhan, berhak mendapat perlindungan dari perlakuan: a. diskriminasi;

b. eksploitasi, baik ekonomi maupun seksual;

c. penelantaran;

d. kekejaman, kekerasan, dan penganiayaan;

e. ketidakadilan; dan

f. perlakuan salah lainnya.

Undang-Undang No. 23 Tahun 2004 tentang Penghapusan Kekerasan Dalam Rumah Tangga menyatakan bahwa kekerasan dalam rumah tangga dapat terjadi salah satu bentuknya adalah berupa adanya pembiaran dari salah satu pasangan, demikian juga adanya pembiaran terhadap anak yang lahir dari perkawinan tersebut, dan bila hal tersebut dilanggar akan ada tuntutan pidana berupa hukuman penjara. Satu hal yang harus disadari oleh pihak yang akan bercerai bahwa kalau melakukan penelantaran terhadap anak meskipun telah bercerai, maka hal tersebut dalam Undang-Undang No. 23 Tahun 2004 tentang Kekerasan Dalam Rumah Tangga, termasuk telah melakukan kekerasan dalam rumah tangga.

Pihak yang melanggar atau tidak melaksanakan tanggung jawab sebagaimana telah dinyatakan di atas, maka ditegaskan pada ketentuan Pasal 49 Undang-Undang No. 23 Tahun 2004 tentang Kekerasan Dalam Rumah Tangga sebagai berikut yaitu dipidana dengan pidana penjara paling lama 3 (tiga) tahun atau denda paling banyak Rp 15.000.000,- (lima betas juta rupiah), setiap orang yang; 
a

menelantarkan orang lain dalam lingkup rumah tangganya sebagaimana dimaksud dalam Pasal 9 Ayat (1);

b. menelantarkan orang lain sebagaimana dimaksud Pasal 9 Ayat (2).

Jelas bahwa orang tua yang menelantarkan anak atau istri yang masih dalam tanggungannya dapat dihukum sesuai dengan pasal-pasal yang telah disebutkan di atas. Menurut pendapat Penulis bahwa undangundang ini masih belum mendapatkan sosialisasi yang maksimal, meskipun laporan ke polisi dalam hal kekerasan dalam rumah tangga seperti penganiayaan telah sering kita dengar, namun untuk kasus penelantaran anak masih jarang kita dengar kecuali beberapa kasus yang pernah di siarkan dalam media elektronik. Padahal sebetulnya banyak kasus serupa yang menimpa anak-anak korban perceraian yang tidak dilaporkan.

\section{KESIMPULAN}

1. Berbagai peraturan perundangundangan di Indonesia, telah menjamin perlindungan terhadap masa depan dan hak-hak anak, khususnya anak yang orang tuanya bercerai. Anak berhak mendapatkan jaminan untuk masa depannya, misalnya biaya hidup, biaya pendidikan, dan pengobatan dari orang tuanya.

2. Anak yang orang tuanya bercerai, adalah pihak yang paling dirugikan, dapat dipastikan bahwa anak akan mengalami tekanan psikologis yang dapat berpengaruh pada masa depannya, sehingga anak perlu mendapatkan perhatian, khususnya oleh lembaga peradilan dapat menjamin hakhak anak dan yang terbaik bagi anak, apabila hak-hak itu diabaikandapatmelakukanupaya hukum dengan permohonan eksekusi putusan pengadilan yang diabaikan.

\section{DAFTAR PUSTAKA}

Buku:

Ali, Zainuddin, 2009, Metode Penelitian Hukum, Sinar Grafika, Jakarta.

Fajar ND, Mukti dan Yulianto Achmad, 2010, Dualisme Penelitian Hukum Normatif dan Hukum Empiris, Pustaka Pelajar, Yogyakarta.

Gultom, Maidin, 2008, Perlindungan Hukum Terhadap Anak dalam Sistem Peradilan Pidana Anak di Indonesia, Refika Aditama, Bandung. , 2012, Perlindungan

HukumTterhadap Anak Dan Perempuan, Bandung: PT. Refika Aditama.

Hadjon, Philipus M., 2007,

Perlindungan Hukum Bagi

Rakyat Indonesia, Peradaban, Jakarta.

Mulyadi, Lilik, 2007, Putusan Hakim 
dalam Hukum Acara Pidana, PT

Citra Aditya Bakti, Bandung.

Mahmud Marzuki, Peter, 2011, Penelitian Hukum, Kencana Prenada Media Group, Jakarta.

Pohan, Agustinus, Topo Santoso, dan Martin Moerings (ed), 2012, Hukum Pidana Dalam Perspektif, Pustaka Larasan, Denpasar.

Salman Otje dan Anton F. Susanto, 2009, Teori Hukum Mengingat, Mengumpulkan dan Membuka Kembali, Refika Aditama, Bandung.

Sutedjo, Wagiati, 2010, Hukum Pidana Anak, Cetakan Ketiga, PT.Refika Aditama, Bandung.

Suyanto, Bagong dan Sri Sanituti, 2002, Krisis \& Child Abuse, Airlangga University, Surabaya.

\section{Jurnal versi online:}

Faisal, Izzah Amila. PARIWISATA SEKSUAL ANAK : UPAYA PERLINDUNGAN ANAK BERKAITAN DENGAN SEX CHILD TOURISM. Jurnal Magister Hukum Udayana (Udayana Master Law Journal), vol. 4 no. 4 edisi desember 2015. <https:// ojs.unud.ac.id/index.php/ jmhu/article/view/19739>. Diakses tanggal 9 maret 2017. doi: <https://doi.org/10.24843/ JMHU.2015.v04.i04.p01.

Sukerti, Ni Nyoman. PENEGAKAN HUKUM TERHADAP HAK
ASUH ANAK AKIBAT PERCERAIAN DALAM PRAKTIK PERADILAN DI BALI. Jurnal Magister Hukum Udayana (Udayana Master Law Journal), vol. 4 no. 1 edisi mei 2015. <https://ojs.unud. ac.id/index.php/jmhu/article/ view/13043>. Diakses tanggal 9 maret 2017. doi: $<$ https://doi. org/10.24843/JMHU.2015.v04. i01.p07.

\section{Internet:}

Tribun Bali, 2017, Istri yang Paling BanyakMinta CeraidiDenpasar, Dipicu Medsos Hingga Urusan Ranjang, available from: URL: http://bali.tribunnews. com/2017/03/11/istri-yangpaling-banyak-minta-ceraidi-denpasar-dipicu-medsoshingga-urusan-ranjang, diakses tanggal 9 Maret 2017

\section{Peraturan Perundang-Undangan:}

Undang-Undang Dasar Negara Republik Indonesia Tahun 1945

Undang-Undang No. 1 Tahun 1974 Tentang Perkawinan, Lembaran

Negara Republik Indonesia Tahun 1974 Nomor 1, Tambahan Lembaran Negara Republik Indonesia Nomor 3019.

Undang-Undang Republik Indonesia Nomor 23 Tahun 2002 Tentang Perlindungan Anak, Lembaran Negara Republik Indonesia Tahun 2002 Nomor 109, 
Tambahan Lembaran Negara

Republik Indonesia Nomor 4235.

Undang-Undang Republik Indonesia

Nomor 23 Tahun 2004 Tentang Penghapusan Kekerasan Dalam

Rumah Tangga, Lembaran

Negara Republik Indonesia

Tahun 2004 Nomor 95, Lembaran Negara Republik Indonesia Tahun 2004 Nomor 4419.

Undang-Undang Republik Indonesia Nomor 35 Tahun 2014 Tentang Perubahan Atas Undang-Undang Nomor 23 Tahun 2002 Tentang Perlindungan Anak, Lembaran Negara Republik Indonesia Tahun 2014 Nomor 297, Tambahan Lembaran Negara Republik Indonesia Nomor 5606. 